\title{
Sosyal Ăg ve Sosyal Medya Platformları Üzerinde Yürütülen Viral Pazarlama Faaliyetlerinin Tüketici Davranışı Üzerindeki Etkisi: İstanbul İli Örneği
}

\author{
The Effect of Viral Marketing Activities on Social Network and Social Media \\ Platforms on Consumer Behavior: The Example of Istanbul Province
}

\author{
Esen $S A H I^{*}$ \\ Malik DÜNDAR** \\ $\ddot{O} Z$
}

Geçmişten günümüze insan hayatında yaşanan değişim ve dönüşüme paralel olarak Internet altyapısının ve iletişim teknolojilerinin gelişmesiyle birlikte çok etkili değişiklikler yaşanmaya devam etmektedir. Bu bağlamda dünya genelinde Internet kullanıcılarının sayısının her geçen gün artmasıla, web tabanlı uygulamalar ve sosyal medya çok daha etkili ve farklı fonksiyonları da kapsayacak şekilde kullanılmaktadır. Insanlar tarafindan günlük hayatta yapılan birçok faaliyetin Internet aracılığıyla kolay bir şekilde gerçekleştiriliyor olması ve taraflar arasında sosyal ă̆lar aracılı̆̆ıyla iletişimin kurulması, ăgızdan ăgza iletişimin web tabanlı boyutu olarak adlandırılan viral pazarlama uygulamalarının da yaygınlaşmasını desteklemiştir. Işsletmelerin yerel ve küresel müşterilere ulaşmasında daha kolay, hızlı ve etkin bir yöntem olmasının yanında, viral pazarlamanın daha az maliyetli olması da yönteme olan ilginin artması sonucunu doğurmuştur. Günümüzde viral pazarlama, sosyal medya kullanımının da yaygınlaşmasılla birlikte işletmeler için etkili bir pazarlama aracı haline gelmiştir. Bu çalışma; kolayda örnekleme yöntemi kullanılarak belirlenen 500 tüketiciye, hazırlanan anketlerin uygulanmasi sonucunda elde edilen verilerin analiz edilmesi ve elde edilen bilgilerin değerlendirilmesi ve yorumlanmasını kapsamaktadır. Çalışmanın temel amacı, sosyal medya kullanımının viral pazarlama uygulamalarına etkisinin olup olmadığını araştırmaktır. Yapılan analizler sonucunda tüketicilerin sosyal medya kullanım düzeyinin viral pazarlama faaliyetlerini pozitif ve anlaml yönde etkilediği görülmüştür.

\section{ANAHTAR KELIMELER \\ Viral pazarlama, Sosyal Medya, Pazarlama \\ ABSTRACT}

Parallel to the change and transformation experienced in human life from the past to the present, with the development of Internet infrastructure and communication technologies, very effective changes continue to occur. In this context, with the increasing number of Internet users worldwide, web-based applications and social media are used to cover more effective and different functions. The fact that many activities carried out by people in daily life are carried out easily via the Internet and communication between the parties through social networks has supported the spread of viral marketing practices called web based dimension of oral communication. In addition to being an easier, faster and more efficient way for businesses to reach local and global customers, the fact that viral marketing is less costly has resulted in an increase in interest in the method. Nowadays, viral marketing has become an effective marketing tool for businesses with the expansion of social media usage. This work; 500 consumers identified by using easy sampling method, analysis of the data obtained as a result of the application of the prepared questionnaires and evaluation and interpretation of the information obtained. The main purpose of the study is to investigate whether the use of social media has an impact on viral marketing practices. As a result of the analyzes, it was observed that the level of social media usage of consumers affected viral marketing activities positively and significantly

KEYWORDS

Viral Marketing, Social Networks, Marketing

\begin{tabular}{|c|c|c|}
\hline \multicolumn{2}{|r|}{$\begin{array}{c}\text { Makale Geliş Tarihi / Submission Date } \\
17.12 .2018\end{array}$} & $\begin{array}{c}\text { Makale Kabul Tarihi / Date of Acceptance } \\
24.01 .2019\end{array}$ \\
\hline Atıf & $\begin{array}{l}\text { Şahin, E. Dündar, M. (2019). Sosya } \\
\text { Faaliyetlerinin Tüketici Davranışı Üze } \\
\text { Yüksekokulu Dergisi, } 22 \text { (1), 143-160 }\end{array}$ & $\begin{array}{l}\text { ya Platformları Üzerinde Yürütülen Viral Pazarlama } \\
\text { İli Örneği. Selçuk Üniversitesi Sosyal Bilimler Meslek }\end{array}$ \\
\hline
\end{tabular}

\footnotetext{
* Dr. Öğr. Üyesi, Selçuk Üniversitesi, İktisadi ve İdari Bilimler Fakültesi, İşletme Bölümü, esenboztassahin@ gmail.com, ORCID: 0000-0001-7215-5018,

** Yüksek Lisans Öğrencisi, Selçuk Üniversitesi, Sosyal Bilimler Enstitüsü, Üretim Yönetimi ve Pazarlama Bilim Dalı, malikdundar34@gmail.com, ORCID: 0000-0002-3599-7336,
} 


\section{GİRIŞ}

Günümüzde hızla gelişen teknoloji, hayatın her alanında köklü değişiklikleri doğurmaktadır. İşletmeler, küresel rekabetin gerisinde kalmamak ve rekabet güçlerini artırmak için teknolojik gelişmeye ve değişime ayak uydurmak zorundadır (Eldem, 2009: 3). İşletmelerin, mevcut ve yeni pazarlarda rekabette başarılı olabilmeleri ve sürdürülebilir avantajlar elde etmeleri için teknolojik gelişmeleri yakından takip etmeleri ve bu değişim e uyum sağlamaları bir zaruri yettir (Nacak, 2012: 4).

Değişen dünyada tüketicilerin ihtiyaçlarını, istekleri doğrultusunda karşılamak için birçok farklı platformda arayış içinde oldukları görülmektedir (Bostanc1, 2010: 3). Örneğin tüketiciler mağazalara gidip alışverişlerini yapmak yerine online alışveriş yaparak çeşitli avantajlar elde edebilmektedir. Tüketicilerin online alışverişi seçmesindeki en önemli etken ise zamandan kazanılan tasarruf ve azalan maliyet olarak öne çıkmaktadır (Solmaz, 2014: 5). Ayrıca günümüzde birçok insan var olan farklı sosyal ağlarda profil oluşturarak ve bu sosyal medya hesaplarını aktif kullanarak birbirleriyle kolayca iletişim kurabilmektedir. Sosyal medya platformları kullanıcılarına paylaşımda bulunma, diğer kullanıcılar ile iletişim kurma ve kendini rahatça ifade edebilme gibi ayrıcalıklar sunarken bir yandan da kullanıcıları için yepyeni ve farklı pazarlama ortamları da oluşmaktadır. Bu yeni ortamlar ile birlikte hem tüketiciler kendi içeriklerini oluşturabilmekte hem de işletmeler rekabetin yoğun olduğu günümüz pazarlarında tüketicilerle iletişim halinde kalarak pazarlama faaliyetlerini 724 aralıksız sürdürebilmektedirler (Güner, 2016: 34). Sosyal ağlar üzerinde yaşanan olumsuz tecrübeler veya viral olarak edinilen negatif duyumlar tüketicinin satın alma kararını olumsuz etkileyebilmektedir. Ayrıca olumsuz paylaşımların tüketiciler arasında viral olarak çok daha hızlı yayılması da işletmelere önemli müşteri kayıpları yaşatabilmektedir (Güner, 2016: 1). Tüm bu gerekçeler nedeni ile sosyal medya platformlarında toplanan kullanıcılar, çeşitli pazarlarda faaliyet gösteren işletmelerin iştahını kabartmaktadır.

$\mathrm{Bu}$ çalışmada; İstanbul ilinde sosyal medya platformlarını kullanan kişilerin, bu platformlarda uygulanan viral pazarlama uygulamalarının satın alma davranışları üzerindeki etkileri ölçülmüş ve elde edilen veriler analiz edilerek ulaşılan sonuçlar yorumlanmıştır.

\section{LITERATÜR ÖZETI}

\subsection{Sosyal Ağlar ve Sosyal Medya}

Sosyal ağlar ilk olarak kullanıcıların dizüstü veya masaüstü bilgisayarlarıyla sadece web sitelerine erişimi sağlamak amacıyla kullanılmıştır. Akıllı telefonların gelişmesiyle, sosyal ağlar mobil uygulama sürümlerini yayınlamışlar ve bu gelişmeyle birlikte kullanıcıların çevrimiçi profillere erişmesi daha aktif ve kolay olmuştur (Aldhafferi, 2013: 2). İnternet kullanım oranlarının dünya genelinde artması ve sosyal medya kullanım düzeyleri paralel bir artış göstermiştir. Dünya da ve Türkiye'de, sosyal medya kullanım oranlarında her yıl daha da etkili bir artış gerçekleşmektedir. Aşağıda Tablo. 1'de Dünya da ve Türkiye'de sosyal medya kullanım oranları ile ilgili istatistiki bilgilere yer verilmiştir.

Tablo 1: Sosyal Medya Kullanım Oranı

\begin{tabular}{lcc}
\hline & Türkiye & Dünya \\
\cline { 2 - 3 } Sosyal Medya Kullanımının Nüfusa Oranı & $60 \%$ & $37 \%$ \\
Sosyal Medya Kullanıcı Sayısı & 48 Milyon & 2.789 Milyar \\
Toplam Nüfus & 80 Milyon & 7.540 Milyar \\
\hline
\end{tabular}

Kaynak: www.wearesocial.com 2017 verilerini kullanarak hazırlanmıştır.

Tablo 1. incelendiğinde Dünya nüfusunun toplam \%37'sinin sosyal medyayı kullandığı görülmektedir. Türkiye'de ise nüfusun \%60'1 sosyal medya kullanmaktadır. Bu oranlar doğrultusunda hem Dünya da hem de Türkiye'de sosyal medyanın çok etkin bir iletişim ağı olduğu söylenebilir.

Sosyal medya; yeni iş şekilleri, sosyal yapılar ve teknoloji sunumların kullanımını teşvik etmek amacıyla insanların içerik ve veri arasındaki etkili etkileşimini kolaylaştıran teknoloji ve uygulamalar bütünüdür (Parlak, 2009: 28). Sosyal medya; medya kullanıcıları ve üreticileri açısından, halka açık içeriği yaratma aşamalarında kullanıcı katılımını sağlamak amacıyla çeşitli imkanları içermektedir (Özel, 2012: 54). Tüketiciler almak istedikleri ürünle ilgili bilgi sahibi olmak, ilgili konuda herhangi bir sorunla karşılaştığı zaman bu sorunu; yetkili birimlere iletmek ve çözmek için karşılarında bir muhatap bulmak isterler. Günümüzde çeşitli sanal platformlarda, tüketiciler bu tür sorunlarla karşılaştığında tüketicilerin bu sorunlarına kolayca çözüm bulmalarına imkan sağlayan alt yapılar bulunmaktadır (Kırcova, 2012: 65). 
İnternet teknolojisi her alanda coğrafi sınırları ortadan kaldırmaktadır. Sanal platformalar üzerinden yapılan alış-veriş sayesinde tüketiciler, zamandan tasarruf edebildikleri gibi birçok ihtiyacı bulundukları konumdan giderebilmek ve böylece farklı coğrafyalarda bulunan ürünleri görüp onlar hakkında bilgi sahibi olabilmek gibi avantajları yaşamaktadır. Bu durum beraberinde tüketici için kalite, kolaylık, rahatlık, güven ve memnuniyeti getirmektedir (Aksoy, 2006: 30). Ayrıca iletişim ve bilgi teknolojileri, ürün alım ve satımlarında; siparişin zaman yönetiminde etkinlik, yüksek kalitede üretim ve rekabet açısından üstün olma gibi fırsatlar sunmaktadır. $\mathrm{Bu}$ tekniklerin mobil sistemler üzerinden kullanımı mobil pazarlama uygulamalarını doğurmuştur. Mobil pazarlama kullanım tekniğine göre farklı amaçlara ve yöntemlere sahiptir. Bu amaçlar; marka kimliğinin yaygınlaşması, ürün farklılığı oluşturmak ve ürün geliştirmek, ürün yerleştirmesini güçlendirmek, ürünün konumunu sağlamlaştırmak, satışları artırmak, tüketici kazanmak, tüketici sadakatini artırmak, ürüne - markaya dikkat çekmek ve ürün tanıtımları yapmaktır (Eru, 2013: 57).

Sosyal medyaya olan ilginin artışı ve pazarlamacıların sosyal medya yatırımlarındaki artış paralellik göstermektedir. Sosyal medya ortamlarında ticarete ilk yıllarda, bu durumun bir İnternet balonu olabileceği endişesiyle çekinilerek ve düşük bütçelerle yaklaşılsa da zamanla hızla artan kullanıcı sayısı, sosyal medya platformlarının iyi bir itibar edinmesini ve bu konudaki kaygılarını azalmasını sağlamıştır (Coşkunkurt, 2013: 8). Sosyal medya; gazete, televizyon ve film gibi geleneksel medyalardan farkl1l1klar göstermektedir. Genellikle geleneksel medya enformasyonun yayınlanması için belirli kaynaklara ihtiyaç duyulur. (Özcan, 2013: 8). Ancak sosyal medyanın sahip olduğu tüketici potansiyeli; dünyada neredeyse tüm ülke, marka, işletme ve hatta kişilerin, kendilerini sosyal medya platformlarında tanıtmaları ve sahip oldukları değerleri insanların ilgisine sunmaya çalışmaları sonucunu ortaya çıkarmaktadır (Bostancı, 2010: 51). İnsanlar kendi ilgi alanları doğrultusunda sosyal medyada zaman geçirmekte, kendi bilgilerini, görüşlerini ve hatta mahremiyetlerini de bu ortamlarda paylaşmaktadırlar (Eryılmaz, 2014: 23). İşletmeler sosyal medya platformlarındaki verileri, amaçlarına uygun olarak bilgiye dönüştürüp, bu bilgileri kullanarak tüketici isteklerini, ihtiyaçlarını ve tüketicideki değişimi takip edebilirler. Bu durum hedef kitleye ulaşma noktasında işletmeler için daha kolay ve daha az maliyetlidir.

İnternet ortamında ürünlerle ilgili paylaşılan bilgiler, diğer iletişim araçlarına kıyasla, bilginin daha geniş bir erişilebilirlik ve esneklikle yayılmasına imkan sağlamaktadır. İnternet ve sosyal ağlarda paylaşılan yer bildirimi ve etkinlik gibi eylemler, tüm dünyada pazarlama anlamında büyük bir hareketlilik oluşmuştur. Bu büyük hareketlilik, İnternet ve sosyal ağ kullanan herkesin, herhangi bir işletme faaliyetinin veya organizasyonunun, bu yöntemle herhangi bir erişim engeline takılmaksızın online ortamda erişilebilirliğini artırmıştır. Viral pazarlama, dünyadaki tüm insanlarla iletişime geçilmesini sağlayarak ve bu süreci kolaylaştırarak, ilgili taraflar arasında, elektronik ticaret yapma imkanı sağlamaktadır (Yazıcı, 2014: 47). Türkiye'de İnternet kullanıcı sayısının yüksek olmasına rağmen, büyüyen perakende pazarında, online perakendecilik, sektörün aldığı toplam payın küçük bir kısmını oluşturmaktadır. Türk tüketicilerin, son yıllarda önemli bir yükseliş içerisinde olmasına rağmen, İnternet yoluyla gerçekleştirdikleri alışveriş beklentilerin altında gerçekleşmektedir. Bu noktada, online alışveriş davranışını etkileyen faktörlerin neler olduğu sorusu önem kazanmaktadır (Gültaş, 2014: 41). Bu durum işletmeleri pazarlama stratejilerini değiştirmeye mecbur bırakmıştır. İşletmeler, tüketicilerinin online alışveriş davranışlarını etkileyen faktörlere yoğunlaşarak, yeni tüketicileri çekme ve mevcut tüketicilerini de elde tutma noktasında daha başarılı pazarlama stratejileri geliştirebilirler. Tüm bu nedenlerden dolayı sosyal medya pazarlaması, dijital pazarlama stratejileri içerisinde önemli bir yere sahiptir (Taş, 2014: 44).

Sosyal medya, çă̆ımızda en sık kullanılan iletişim araçlarından birisidir ve İnternetin en eşsiz uygulamaları içerisinde yer almaktadır. İnternet ve sosyal medya kullanım oranları paralel şekilde artmaktadır. Yakın bir zamanda İnternet kullanım oranlarının çok önemli bir kısmının sosyal medya kullanımdan meydana geleceği tahmin edilmektedir. Sosyal medya uygulamaları taraflar arasında sadece iletişim kurma imkanı ile sınırlı kalmayıp; bilgi edinme, oyun oynama, film ve video izleme, banka işlemleri vs. gibi pek çok kullanım seçeneği sağlayarak kullanıcıların pek çok ihtiyacını karşılayabilmektedir (Hazar, 2011: 157). Sosyal ağların kullanıcılara sunduğu hizmetlerin ortak özellikleri arasında kullanıcılara, bağlantılar aracıllı̆ıyla iletişim kurma ve işbirliği yapma olanağı sağlamaları sayılabilir. Sosyal medya kullanımının yaygınlaşması ile birlikte insanların yer, zaman ve mekan faydasını en üst seviyeye çıkarması söz konusu olmuş ve beraberinde günümüzdeki insan alışkanlıkları da bu yönde değişmiştir (Genç, 2015: 7).

\subsection{Viral Pazarlama Kavramı}

Viral pazarlama, insanların yakın arkadaşları, eşleri veya örnek aldığı kişilerin tükettiği ürünler hakkında yapmış olduğu olumlu ya da olumsuz yorumları ağızdan ağza yayılmasına verilen isimdir (Coney, 1998: 238). 
Başka bir tanıma göre viral pazarlama, bir kişinin diğer tüketicilerle herhangi bir telefon sohbetinde, e-posta yoluyla ya da online sohbet ortamında kişilerle almış oldukları ürünler hakkında sohbet etmeleridir (Schiffman, 2004: 500). Günümüzde çoğu insan viral pazarlamayı sadece e-posta aracılığıyla gerçekleştiğini düşünür (Bannan, 2002: 20). Fakat genel olarak viral pazarlama, insanların kendi aralarında sözlü olarak, mesajı iletenin alıcıya mal ve hizmetle ilgili ticari olmayan mesajlar sunduğu iletişim aracıdır. İki ya da daha fazla kişi arasında düşüncelerin karşılıklı değişime uğradığı iletişim aracıdır (Lam, 2005: 217). Viral pazarlamayı insanların birbirileri arasında görünmeyen bir bilgi akışı gibi düşünmek mümkündür. Tüketiciler ücret ödeyerek aldıkları ürünler hakkında sosyal medya platformların da yorum yaparak birbirlerini etkilemektedir. $\mathrm{Bu}$ açıdan değerlendirildiğinde işletmelerin, müşteri ilişkileri ve memnuniyetine daha çok önem vermeleri gerektiği sonucuna ulaş1lmaktadır (Rosen, 2000: 12).

\subsection{Viral Pazarlamanın Türleri}

Aşağıda viral pazarlama türleri hakkında çeşitli bilgilere yer yerilmiştir.

\subsubsection{Aktif Viral Pazarlama}

Aktif viral pazarlama, kullanıcının kişisel olarak yeni müşteriler kazanma çabasıdır. Kullanıcılar ücretsiz olarak kullandığı viral linkler yoluyla arkadaş ve aile çevresine bu hizmeti alması konusunda güven vererek kişileri cesaretlendirir (Skrob, 2005: 6). Aktif viral pazarlamanın diğer bir uygulama şekli de promosyonlu pazarlama türüdür. Bunun en temel ve başarılı örneği Amazon İnternet Sitesi'dir. Amazon İnternet Sitesi aracılığıyla kullanıcılara yayılan linklerden siteye üye olunduğunda her yeni üye için kişilere ödeme yapılmakta ve ödüller vermektedir. Bu uygulamayla Amazon İnternet Sitesi üyelik sisteminde aktif viral pazarlama etkili bir şekilde kullanılmaktadır (Skrob, 2005: 6).

\subsubsection{Temassiz Viral Pazarlama}

Temassız viral pazarlama, genel viral pazarlama uygulamalarının aksine reklam ve bilgi paylaşımı yapılmasına gerek duymaz. Temassız viral pazarlamanın genel olarak uygulanışı; ürünü, promosyon mesaj1 aracılığıyla müşteriyle direkt buluşturmasıdır. Bu tip viral pazarlamanın en iyi kullanıldığı örneklerden birisi Hotmail'in yöntemi ve uygulamasıdır. Bu örnekte ürünlerle ilgili promosyonlar mailler aracilığıyla tüketiciye direkt iletir (Skrob, 2005: 7).

\subsection{Viral Pazarlamanın Avantajları}

Viral pazarlama kullanım oranlarının her geçen gün artıyor olasının altında yöntemin sağladığı önemli avantajlar yatmaktadır. Viral pazarlama yolu ile yürütülen bir kampanya çok etkin, düşün maliyetli ve hızlı bir şekilde hedef kitleye ulaşır. Viral pazarlamanın etkin bir şekilde yayılmasını sağlayan en önemli nokta, hem mesaj1 ileten hem de mesajı alan kişinin ikna edici unsur pozisyonunda olmasıdır (Wilson, 2000: 13). Viral pazarlamada, katılma ve paylaşma kararı her zaman kullanıcıdan gelir ve bu nedenle taraflar birbirleriyle etkileşim içindedir. Bu şekilde, markanın algılanışı ve etkileşimi, klasik reklam biçimlerine kıyasla önemli derecede daha iyidir. Sosyal ağlar günümüzde toplumsallaşmaya yeni bir boyut ve ivme kazandırmıştır. Dolayısıyla, akrabalar ve arkadaşlar ağ üzerinden birbirlerine kolayca erişilebilir durumdadır.

Viral pazarlama, sanal ticari işlemi teşvik eden en düşük maliyetli yöntemlerden biridir. Bu yöntemde zaman etkin kullanılırken, işlemler için gerekli kaynaklar da kolayca elde edilebilir. Bu pazarlama türünde, bir kişi arkadaşlarıyla veya akrabalarıyla iletişim kurarken zamanla daha çok insanla temasa geçer ve bu zincirleme iletişim ağı devam ettiği müddetçe de reklamlardan gelir elde edilir (Brow, 2010: 12).

İnternet ortamında ürünlerini pazarlamaya çalışan günümüz işletmeleri, sosyal ağların gücünün ve etkinliğinin farkındadırlar. İşletmeler, İnternet kullanıcılarının e-posta ve favori web site adresleri aracılığı ile haklarında bilgi toplamaktadır. İşletmeler, insanlar arasındaki iletilere istedikleri mesajları ekleyerek bu ağlardan faydalanır. Bu uygulamalara en başarılı örnek İnternet tarayıcılarının sağlamış oldukları çerezlerdir (Sim, 2012: 5). Bu çerezler sayesinde tüketicilerin online ortamlarda hangi ürünle ilgilendiği belirlenebilmekte ve bu veriler 1şığında online ortamlarda kullanıcılara reklamlar aracılığı ile ulaşmak mümkün olmaktadır. Böylece pazarlama içerikli mesajlar da kolay ve bozulmaksızın aktarılabilecek şekilde basitleştirilmektedir (Balc1, 2013: 87).

\subsection{Viral Pazarlamanın Dezavantajları}

Viral pazarlamanın avantajlarının yanın da dezavantajları da vardır. Örneğin, insanların e-posta adresine gelen çok miktarda e-posta can sıkıcı olabilir ve bazıları da istenmeyen (spam) mesajlar olarak filtrelenir. Viral pazarlama, sadece, ilgili mesajı potansiyel tüketicilere çevrimiçi yollarla yaymakla işletmelere fayda sağlamaz 
(Yayla, 2010: 71). İşletmeler, viral pazarlama uygulamalarını, tüketicilerin satın alma motivasyonunu etkilemek için kullanmak istiyorlarsa, burada başarı; doğrudan viral pazarlamaya atfedilebilecek sonuçların tanımlanamayacağı, viral pazarlamaya dayalı olmayan tüketici kara kutularına (uyarıcı-tepki) da bağlıdır. İnsanların, e-postalar yoluyla mesaj yaymak ve diğer iletişim araçlarıyla insanlara iş organizasyonları için pazarlama yapmak yerine kendi kişisel işlerine yoğunlaşmalarını sağlamak çok daha zordur (Mark, 2011: 25).

Viral pazarlamaya yönelik çabalar, ürün mesajının hedef kitleye ulaşmasını hedeflerken; bu süreçte, hedef olmayan kullanıcılara da viral yollarla ulaşılabilir ve farklı kitlelerde ürüne ilgi uyanabilir. İnternet üzerindeki herkes kolayca pazarlama kampanyaları başlatabileceği için, rakipler tarafindan viral kampanyalar kolayca taklit edilebilir. Ayrıca viral pazarlama içeriklerinde negatif tanıtımın, olumlu tanıtımla aynı hızda, hatta olumlu tanıtımdan daha yüksek hızda yayılması mümkündür (Glen, 1993: 7). IBM'in yaptığı bir araştırmaya göre online alışveriş yapan tüketicilerin \%78'i kişisel bilgilerinin kimlik hırsızları ya da site tarafından çalınacağından kaygılanmaktadır. Bu güvensizlikle nasıl başa çıkılacağı konusunda ciddi çalışmaların yapılması gerekir (Cevher, 2014: 23). İşletmeler bu negatif algının üstesinden gelebilmek için tüketicilerin güvenini kazanmalı ve kimliklerin gizliliğine karşı gösterdikleri hassasiyeti sitelerinde açıkça beyan etmelidirler. Müşterileri, kişisel bilgi ya da IP adresleri gibi verilerin korunmasında ne gibi yöntemler kullandıkları, tedbirler aldıkları noktasında bilgilendirmeli ve müşterilerin güvenlerini kazanmalıdırlar.

\subsection{Sosyal Paylaşım Sitelerinde Viral Pazarlama}

Sosyal ağ ve sosyal medyaya olan ilgilinin hızla artması, işletmelerin bu platformlarda yürütülen viral pazarlama kampanyalarına olan yönelimlerini artırmıştır (Ünal, 2011: 57). Kullanıcıların İnternet ve diğer uygulamaları kullanım oranları farklılık gösterdiği için viral pazarlama ile ilgili yapılan planlar ve stratejiler de işletmelerde farklılık gösterebilir. Bu sebeple viral pazarlama stratejileri düşük ve yüksek katılımcı stratejisi olarak ikiye ayrılarak değerlendirilir. Düşük katılım stratejisinde, sosyal medya aracılığıyla konan herhangi bir bilgi bağlantısının altına "arkadaşına gönder-arkadaşınla paylaş" butonu eklenerek kullanıcının bu bilgiyi arkadaşlarıyla paylaşması sağlanmaktadır. Kullanıcının sosyal platformlarda bu bağlantıyı paylaşmak dışında ekstradan bir işlem yapılmasına gerek yoktur. Bu viral pazarlama yayılma modelinde, İnternet ortamında adres ve iletişim bilgileri, takvimler, haber grupları, arama motorları ve tebrik kartları gibi hizmetler kullanılabilir Yüksek katılım stratejilerinde ise yeni kullanıcılar talep edilmektedir. Facebook, Twitter ve Instagram gibi sosyal katılım ağlar, yüksek katılım stratejisine birer örnektir (Argan, 2006: 26).

\section{METODOLOJI}

\subsection{Araştırmanın Yöntemi ve Örneklem}

Çalışmanın ana kütlesini; tüketim hacmi, tüketici alışkanlıkları, kültürel farklılığı ve çeşitli etnik yapıları bünyesinde barındıran kozmopolit yapısından dolayı İstanbul ilinde ikamet eden tüketiciler oluşturmaktadır. TÜIK 2017 verilerine göre İstanbul'un ana kütlesini 15 milyon kişidir (http://www.tuik.gov.tr/UstMenu.do?metod=temelist). Ana kütlenin tamamına, zaman ve maliyet kısıtlarından dolayı ulaşılmayacağı için bu çalışma ana kütleyi temsil etme yeteneğine sahip örneklem kütle üzerinden yürütülmüştür. Örneklem sayısı belirlenirken Yazıcıŏglu ve Erdoğan tarafından hazırlanan ana kütleyi temsil edebilecek örneklem sayısını belirlemede kullanılan tablo referans alınmıştır (Yazıcıŏlu ve Erdoğan, 2004: 50). Bu tablo doğrultusun da İstanbul ili için örnekleme; $\pm 0,10$ örnekleme hatası; $p=0,05$ (ana kütledeki X'in gözlenme oranı) ve q=0,05 (ana kütledeki X'in gözlenme oranı) olmak kaydıyla belirlenen örnek kütle sayısı 394 tüketici olarak belirlenmiştir. Bu bağlamda, homojen bir yapıya sahip olan cevap vericilere 500 anket formu dağıtılmış ancak geri dönen sayı 476 anket olmuştur. 24 anket formu eksik ve hatalı veri girişi dolayısıyla analize dâhil edilmemiştir. Çalışmada 46 sorudan oluşan ve Gunawan ve Huang (2015) tarafından geliştirilen ve Güner (2015) tarafından Türkçe'ye uyarlanan "Sosyal Ağ ve Medya Sitelerinde Viral Pazarlama" ölçeği kullanılmıştır. Orijinal ölçeği geliştiren araştırmacılardan ve ölçeği Türkçe'ye uyarlayan Güner'den, ölçeği çalışmada kullanmak üzere gerekli izinler alınmıştır. Gönderilen orijinal anket formu Güner tarafından Türkçeleştirilmiş, güvenirliliğini ve geçerliliğini ölçmek için tekrar İngilizceye çevrilerek gerekli kontroller yapılmıştır (Güner, 2016: 65). Yapılan değerlendirmeler sonucu anket formu son halini almış ve formlar 01-20 Ağustos 2018 tarih aralığında örneklem grubunu temsil eden kişilere uygulanarak sonuçlar toplanmıştır.

Araştırmada kullanılan anket formu iki bölümden oluşmaktadır. İlk bölümde katılımcıların demografik özelliklerini belirleyen sorular yer almaktadır. İkinci bölümde ise "Sosyal A $\breve{g}$ ve Sosyal Medya Sitelerinde Yer Alan Viral Pazarlamanın Etkisi Ölçeği”"ne ait sorular yer almaktadır. Ölçeklerdeki maddeler 5'li Likert 
derecelendirmesiyle ölçeklendirilmiş olup ölçekte; 1= Kesinlikle Katılmıorum, 2= Katılmıyorum, 3= Kararsızım, 4= Katılıyorum, 5= Kesinlik Katılıyorum anlamındadır.

$\mathrm{Bu}$ araştırmada tesadüfi olmayan kolayda örnekleme yöntemi kullanılmıştır. Tesadüfi olmayan kolayda örnekleme yöntemi, veriler daha hızlı ve kolay bir toplandığı için tercih edilmiştir. Bu yöntemde örneklemeye dahil edilecek birimleri, araştırmacı; önceki bilgi, deneyim ve gözlemlerinden hareketle araştırmanın amacına uygun olarak kendi yargisıyla belirlemektedir (Ural, 2013: 23).

\subsection{Araştırma Modeli ve Hipotezler}

Tanımlayıcı araştırma, belirli amaçlar doğrultusunda ve sistemli süreçler yoluyla veri toplama ve toplanan verilerin analizi olarak tanımlanabilir (Balcı, 2013: 26). Bu kapsamda araştırmanın modeli, modelde kullanılan değişkenler ve ölçekler Gunawan ve Huang (2015)'in çalışmalarından faydalanılarak hazırlanmıştır. Orijinal çalışma Endonezya'da 120 öğrenci üzerinde uygulanmış ve Journal of Business Research'de 2015 yılında yayınlanmıştır. Araştırmanın modeli üç farklı amaç doğrultusunda kurulmuştur. Bu amaçlar sırasıyla,

- "Sosyal A $\breve{g}$ ve Medya Sitelerinde Viral Pazarlama Uygulamaları" ölçeği alt boyutlarından, Bilgi Kullanımına İlişkin Tutum (T) boyutunun Argüman-Kaynak Kalitesi (AK) ile Davranışsal Niyet (DN) arasındaki aracı etkisinin belirlenmesi,

- “Sosyal A $\breve{g}$ ve Medya Sitelerinde Viral Pazarlama Uygulamaları” ölçeği alt boyutlarından, Öznel Normlar (ÖN) boyutunun Sosyal Bütünleşme (SB) ile Davranışsal Niyet (DN) arasındaki aracı etkisinin belirlenmesi,

- "Sosyal A $\breve{g}$ ve Medya Sitelerinde Viral Pazarlama Uygulamaları" ölçeği alt boyutlarından, Algılanan Risk (AR) boyutunun Davranışsal Niyet (DN) üzerindeki etkisinin belirlenmesi, şeklinde olup, Şekil 1'de verilmiştir.

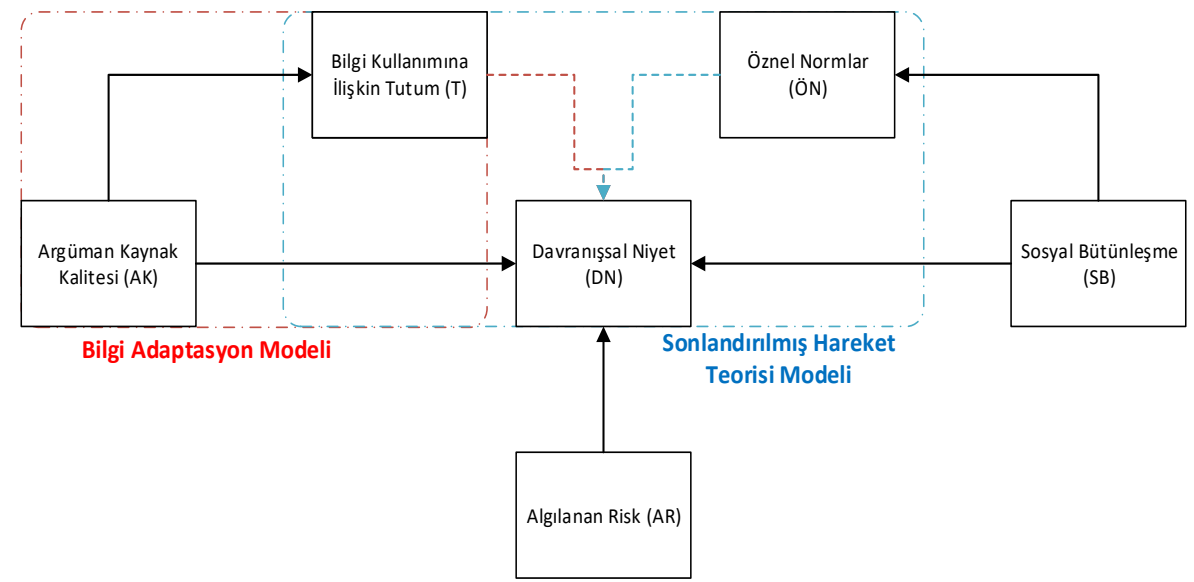

Şekil 1. Araştırma Modeli

Araştırmanın modelinde bahsedilen etkilerin tespit edilmesi, ayrıca Sosyal A $\breve{g}$ ve Medya Sitelerinde Viral Pazarlama ölçeğinde yer alan alt boyutlara ilişkin algıların cinsiyete göre farklılık gösterip göstermediğini belirlemek amacıyla aşağıdaki hipotezler ele alınmıştır.

Hipotez 1 (H1): Argüman- Kaynak Kalitesi (AK) ile Davranışsal Niyet (DN) boyutu arasında Bilgi Kullanımına İlişkin Tutumun (T) aracı etkisi vardır.

Hipotez 2 (H2): Sosyal Bütünleşme (SB) ile Davranışsal Niyet (DN) boyutu arasında öznel normların (ÖN) arac1 etkisi vardır.

Hipotez 3 (H3): Ürüne İlişkin Algılanan Riskin(AR) Davranışsal Niyet (DN) üzerinde etkisi vardır.

Hipotez 4 (H4): Cinsiyete göre Sosyal A ̆g ve Medya Sitelerinde Viral Pazarlama ölçeği alt boyutları puan ortalamaları farklılık göstermektedir.

\subsection{Aracılık Etkisi}

İki değişken arasındaki sebep-sonuç ilişkisinde ek bir başka değişkenin varlığı araştırmacıyı aracı değişkene götürür. Değişkenler arasındaki ilişkide bir aracı değişkenin varlığının tespiti için Baron ve Kenny (1986) tarafindan belirlenen aşağıdaki aşamalar dikkate alınmalıdır. Bu aşamalar,

- Bağımsız değişkenin aracı değişken üzerine istatistiksel olarak anlamlı etkisi olmalıdır.

- Bağımsız değişkenin bağımlı değişken üzerine istatistiksel olarak anlamlı etkisi olmalıdır. 
- Bağımsız değişkenin, aracı değişken üzerinden bağımlı değişkene var olan istatistiksel anlamlı etkisinin azalması kısmi aracılığa işaret etmesi iken, anlamlılığını yitirmesi tam aracılığa işaret etmesidir.

\subsection{Araştırmada Kullanılan Ölçek}

Sosyal ağ ve medya sitelerini kullanan kişilerin viral pazarlama yoluyla davranışsal niyetini ölçmek amacıyla yukarıda "Araştırmanın Yöntemi ve Örneklem" başlığında belirtilen "Sosyal Ăg ve Medya Sitelerinde Yer Alan Viral Pazarlama" ölçeği kullanılmıştır. Bu ölçek 46 maddeden oluşmaktadır ve ölçeğin 7 boyutu vardır. Bu boyutlar; davranışsal niyet (DN) boyutu (4 madde), bilgi kullanımına ilişkin tutum (T) boyutu (5 madde), ürüne ilişkin algılanan risk (AR) boyutu (4 madde), öznel normlar (ÖN) boyutu (4 madde), kişisel algılanan risk (KAR) boyutu (3 madde), sosyal bütünleşme (SB) boyutu (3 madde) ve argüman-kaynak kalitesi (AK) boyutu (3 madde)'dir. Ölçekte yer alan boyutların açıklamaları aşağıda yer almaktadır.

- Davranışsal Niyet (DN): Kişinin satın alma davranışını etkileyebilecek faktörleri içermektedir.

- Bilgi Kullanımına İlişkin Tutum (T): Sosyal medya aracıllğıyla kişilerin elde ettikleri bilgiler doğrultusunda satın almaya karşı takındıkları tutumlardır.

- Ürüne İlişkin Algılanan Risk (AR): Sosyal ağlarda ürüne ilişkin istenmeyen sonuçlar durumunda kaybedilen değerin önem derecesidir.

- Öznel Normlar (ÖN): Bir kişinin bir davranışı gerçekleştirip gerçekleştirmeme konusunda kendisi için önemli bulduğu kişilerin düşüncelerine olan inancıdır.

- Kişisel Algılanan Risk (KAR): Tüketicilerin ve satıcıların, sosyal medya üzerinden belirli bir ürüne ilişkin satın alma durumunda ki ortaya çıkabilecek olumsuz sonuçtur.

- Sosyal Bütünleşme (SB): Bir toplumu oluşturan sosyal yapının çeşitli öğeleri arasındaki birbirini tamamlayabilme durumudur.

- Argüman-Kaynak Kalitesi (AK): Sosyal ağ ve sitelerinde bulunan argümanların tüketicilerin satın alma davranışını etkileyen unsurdur.

\subsection{Araştırmanın Bulguları}

Araştırmada yer alan anket iki bölümden oluşmaktadır. İlk bölümde, araştırmaya katılanların demografik özelliklerini ortaya çıkarabilmek amacıyla, cinsiyet, eğitim durumu, meslek, gelir durumu ve sosyal medya kullanım araçlarına ilişkin sorular yer almaktadır. Bu bağlamda elde edilen demografik özellikler ve sosyal medya kullanım araçlarına ilişkin sonuçlar Tablo 2 ve Tablo 3'de verilmiştir.

\section{Tablo 2: Araştırmaya Katılanların Demografik Özellikleri}

\begin{tabular}{llccc}
\hline Demografi Özellik & & Sayı (n) & Yüzde (\%) & Toplam \\
\hline Cinsiyet & Kadın & 236 & 49,6 & 476 \\
& Erkek & 240 & 50,4 & \\
\hline Yaş & 17-22 Yaş & 44 & 9,0 & \\
& 23-28 Yaş & 181 & 38,0 & 476 \\
29-34 Yaş & 54 & 11,0 & \\
& 35-40 Yaş & 96 & 20,0 & \\
& 41 ve üzeri Yaş & 100 & 21,0 & 476 \\
\hline Eğitim Durumu & İlköğretim Mezunu & 61 & 12,8 & \\
& Lise Mezunu & 90 & 18,9 & \\
& Üniversite Mezunu & 265 & 55,7 & 476 \\
& Lisansüstü Mezunu & 60 & 12,6 & \\
\hline Meslek & Öğrenci & 119 & 25 & \\
& İşçi & 103 & 21,6 & \\
& Emekli & 60 & 12,6 & \\
& Ev Hanımı & 50 & 10,5 & 476 \\
& Memur & 140 & 29,4 & \\
\hline Gelir Durumu & Diğer & 4 & 0,8 & \\
& $0-1500$ TL & 176 & 37,0 & \\
& $1501-3000$ TL & 119 & 25,0 & \\
& 3001-4500 TL & 87 & 18,3 &
\end{tabular}


4501 ve üzeri TL

94

19,7

Araştırmaya katılanların \%50,4'ü erkek, \%49,6'sı kadındır. Yaş gruplanı incelendiğinde, \%9'u 17-22 yaş, \%38'i 23-28 yaş, \%11'i 29-34 yaş, \%20'si 35-40 yaş ve \%21'i ise 41 ve üzeri yaş aralığındadır. Katılımcıların eğitim durumları göz önüne alındığında, büyük oranda üniversite mezunu (\%56) olduğu görülmektedir. Araştırmada en çok \%29,4'lük oran ile mesleği memur ve \%37'lik oran ile aylık geliri 1500 TL ve altı gelir grubunda yer alan katılımcılara ulaş1ldığ görülmektedir (Tablo 2).

Tablo 3: Araştırmaya Katılanların Aktif Sosyal Medya Kullanım Araçları

\begin{tabular}{lcc}
\hline Sosyal Medya Araçları & Sayı (n) & Yüzde (\%) \\
\hline Facebook & 136 & 28,6 \\
Twitter & 72 & 15,1 \\
Pinterest & 8 & 1,7 \\
Instagram & 158 & 33,2 \\
Youtube & 69 & 14,5 \\
Flickr & 5 & 1,1 \\
Google Plus & 28 & 5,9 \\
Toplam & 476 & 100,0 \\
\hline
\end{tabular}

Araştırmaya katılanların aktif olarak kullandıkları sosyal medya araçlarına dair yüzdeler Tablo 3'de verilmiştir. Elde edilen bulgulara göre, katılımcıların en çok tercih ettikleri sosyal medya araçlarının \%33,2 ile Instagram ve \%28,6 ile Facebook olduğu görülmektedir. Hamid vd. (2017:26-29)'nin 50 kişi örneklemli araştırmasında, kullanıcıların \%26'sı Instagram, \%52'si Facebook \%10'nun ise Youtube kullanıcısı olduğu görülmektedir. (Güner, 2016: 69)'in araştırmasında ise kullanıcıların \%22'si Instagram, \%25'i Facebook ve \%22'si Youtube kullanıcısıdır. Çalışmalar arasında örneklem farklılıklarından kaynaklandığı düşünülen, aktif kullanılan sosyal medya araçları kullanım oranlarda değişkenlik dikkat çekmektedir.

\subsection{Sosyal Ă̆ ve Medya Sitelerinde Yer Alan Viral Pazarlama Ölçeği}

Çalışmanın bu kısmında ele alınan ölçeğin alt boyutlarına ilişkin tanımlayıcı istatistikler ve araştırma modeli için ele alınan hipotezlere ilişkin istatistiksel analiz sonuçları yer almaktadır.

Tablo 4: Davranışsal Niyet Alt Boyutuna İlişsin Tanımlayıcı İstatistikler

\begin{tabular}{lcc}
\hline Faktör/Alt Boyut ve Maddeler & Ort. & SS \\
\hline Davranışsal Niyet (DN) & & \\
Sosyal ağ ve sosyal medya sitelerinde viral olarak pazarlanan ürünler satın almaya değerdir. & 2,96 & 1,10 \\
$\begin{array}{l}\text { Sosyal ağ ve sosyal medya sitelerinde viral olarak pazarlanan ürün-hizmetlerle alakalı olan } \\
\text { tartışmalara gelecekte de sık sık katılacağım. }\end{array}$ & 2,77 & 1,28 \\
$\begin{array}{l}\text { Sosyal ağ ve sosyal medya sitelerinde yayınlanarak viral olarak pazarlanan yeni ürün ve } \\
\text { hizmetleri almaya niyet ederim. }\end{array}$ & 3,07 & 1,11 \\
$\begin{array}{l}\text { Gelecekte sosyal ağ ve sosyal medya sitelerinde pazarlanacak olan bir ürün hizmeti almayı } \\
\text { düşünüyorum. }\end{array}$ & 3,35 & 1,15 \\
$\begin{array}{l}\text { Genel } \\
\text { Cronbach's } \text { Alpha }\end{array}$ & $\mathbf{3 , 0 4} \mathbf{0 , 8 5}$ \\
\hline
\end{tabular}

Not: (i) n=475. (ii) Ölçekte 1= Kesinlikle Katılmıyorum, 2=Katılmıyorum, 3= Kararsızım, 4= Katılıyorum, 5= Kesinlik Katılıyorum anlamındadır. (iii) Friedman çift yönlü Anova testine göre $\chi^{2}=92,146$; $p<0,05$ sonuçlar istatistiksel bakımdan anlamlıdır. Ort: Ortalama, SS: Standart Sapma

Davranışsal niyet alt boyutuna ilişkin tanımlayıcı istatistikler incelendiğinde, ortalaması en yüksek olan maddenin 3,35 ile "Gelecekte sosyal ağ ve medya sitelerinde pazarlanacak olan bir ürün hizmeti almay1 düşünüyorum" ve ortalaması 2,77 ile en düşük olan maddenin ise "Sosyal ağ ve medya sitelerinde viral olarak pazarlanan ürün-hizmetlerle alakalı olan tartışmalara gelecekte de s1k s1k katılacağım” olduğu görülmektedir. Alt boyuta ilişkin güvenilirlik analizi ile elde edilen Cronbach's Alpha değeri 0,71 olarak hesaplanmıştır. Bu sonuca göre "Davranışsal Niyet Boyutun"da elde edilen sonuçların güvenilir olduğu söylenebilir (Tavşanc1,2006). 
Tablo 5: Bilgi Kullanımına İlişkin Tutum Alt Boyutuna İlişsin Tanımlayıcı İstatistikler

\section{Faktör/Alt Boyut ve Maddeler}

\section{Bilgi Kullanımına İlişkin Tutum (T)}

Sosyal ağ ve sosyal medyada tartışılan ürün ve hizmetlerin benim için yararlı olduğunu düşünürüm.

Sosyal ağ ve sosyal medyada tartışılan ürün ve hizmetlere ilişkin olumlu fikre sahibim. Genelde, viral olarak pazarlanmış ürün-hizmetlerle ilgili olarak tutumum olumludur.

Sosyal ağ ve sosyal medyada tartışılan ürün ve hizmetlerin benim için iyi olduğunu düşünürüm.

Sosyal ağ ve sosyal medyada tartış1lan ürün ve hizmetlerin benim için uygun olduğunu düşünürüm.

\section{Genel}

Cronbach's Alpha

\section{Ort. SS}

$3,01 \quad 1,13$

$3,03 \quad 1,14$

$3,19 \quad 1,02$

$3,00 \quad 1,17$

$3,11 \quad 1,20$

Not: (i) $n=475$. (ii) Ölçekte $1=$ Kesinlikle Katılmıyorum, $2=$ Katılmıyorum, $3=$ Kararsızım, $4=$ Katıllyorum, $5=$ Kesinlik Katıliyorum anlamindadır. (iii) Friedman çift yönlü Anova testine göre $\chi^{2}=15,037 ; p<0,05$ sonuçlar istatistiksel bakımdan anlamlıdır. Ort: Ortalama, SS: Standart Sapma

Bilgi kullanımına ilişkin tutum alt boyutuna ilişkin tanımlayıcı istatistikler incelendiğinde, ortalaması en yüksek olan maddenin 3,19 ile "Genelde, viral olarak pazarlanmış ürün-hizmetlerle ilgili olarak tutumum olumludur." ve ortalaması 3,00 ile en düşük olan maddenin ise "Sosyal ağ ve sosyal medyada tartış1lan ürün ve hizmetlerin benim için iyi olduğunu düşünürüm" olduğu görülmektedir. Alt boyuta ilişkin güvenilirlik analizi ile elde edilen Cronbach's Alpha değeri 0,74 olarak hesaplanmıştır. Bu sonuca göre "Bilgi Kullanımına İlişkin Tutum Boyutu”nda elde edilen sonuçların güvenilir olduğu söylenebilir (Tavşancıl, 2006).

Tablo 6: Ürüne İlişkin Algılanan Risk Alt Boyutuna İlişkin Tanımlayıcı İstatistikler

\section{Faktör/Alt Boyut ve Maddeler Ürüne İlişkin Algılanan Risk (AR)}

Ort. SS

Viral olarak sosyal ağ ve sosyal medya sitelerinde pazarlanan mamül ve hizmetlerin riskli

olduğuna inanmaktayım. Çünkü gönderilen bu ürün ve hizmetlerin dağıtımı benim beklentimi

karşılamada başarısız olabilir.

Viral olarak sosyal ağ ve sosyal medya sitelerinde pazarlanan mamül ve hizmetlerin riskli

olduğuna inanmaktayım. Çünkü gönderilen bu mamül ve hizmetler düşük kaliteli olabilirler.

Viral olarak sosyal ağ ve sosyal medya sitelerinde pazarlanan mamül ve hizmetlerin riskli

olduğuna inanmaktayım. Çünkü gönderilen bu mamül ve hizmetlerin kullanımı tehlikeli

olabilir.

Viral olarak sosyal ağ ve sosyal medya sitelerinde pazarlanan mamül ve hizmetlerin riskli

olduğuna inanmaktayım. Çünkü bu mamül ve hizmetler, başka bir yerde daha ucuz olabilir.

\begin{tabular}{lc}
\hline Genel & $3,33 \quad 0,94$ \\
Cronbach's Alpha & 0,83 \\
\hline
\end{tabular}

Not: (i) $n=475$. (ii) Ölçekte 1= Kesinlikle Katılmıyorum, 2= Katılmıyorum, 3= Kararsızım, 4= Katılıyorum, 5= Kesinlik Katılıyorum anlamındadır. (iii) Friedman çift yönlü Anova testine göre $\chi^{2}=5,591$; $p<0,05$ sonuçlar istatistiksel bakımdan anlamlıdir. Ort: Ortalama, SS: Standart Sapma

Ürüne ilişkin algılanan risk alt boyutuna ilişkin tanımlayıcı istatistikler incelendiğinde, ortalaması en yüksek olan maddenin 3,37 ile "Viral olarak sosyal ağ ve sosyal medya sitelerinde pazarlanan mamül ve hizmetlerin riskli olduğuna inanmaktayım. Çünkü gönderilen bu ürün ve hizmetlerin kullanımı tehlikeli olabilir." ve ortalaması 3,26 ile en düşük olan maddenin ise "Viral olarak sosyal ağ ve sosyal medya sitelerinde pazarlanan mamül ve hizmetlerin riskli olduğuna inanmaktayım. Çünkü bu mamül ve hizmetler, başka bir yerde daha ucuz olabilir." Olduğu görülmektedir. Alt boyuta ilişkin güvenilirlik analizi ile elde edilen 
Cronbach's Alpha değeri 0,83 olarak hesaplanmıştır. Bu sonuca göre "Ürüne İlişkin Algılanan Risk Boyutu"nda elde edilen sonuçların yüksek güvenilir olduğu gözlemlenmektedir (Tavşanc1l, 2006).

Tablo 7: Öznel Normlar Alt Boyutuna İlişkin Tanımlayıcı İstatistikler

Faktör/Alt Boyut ve Maddeler Ort. SS Öznel Normlar (ÖN)

Mamül ve hizmetlerle ilgili olarak sosyal ağ ve sosyal medyada yer alan sitelerdeki görüşleri $3,11 \quad 1,18$ benimseyebilirim.

Arkadaşlarım sosyal ağ ve sosyal medyada tartışılan ve viral olarak pazarlanan mamül ve hizmetleri satın almam gerektiğini düşünmektedirler.

Meslektaşlarım sosyal ağ ve sosyal medyada tartışılan ve viral olarak pazarlanan mamül ve hizmetleri satınalmam gerektiğini düşünmektedirler.

Satın alma davranışımda etkisi olan insanlar, sosyal ağ ve sosyal medya sitelerinde viral olarak $\quad 3,24 \quad 1,14$ pazarlanan mamül ve hizmetleri almam konusunda beni cesaretlendirebilir.

\begin{tabular}{lc}
\hline Genel & $3,09 \quad 0,93$ \\
Cronbach's Alpha & 0,78 \\
\hline
\end{tabular}

Not: (i) $n=475$. (ii) Ölçekte $1=$ Kesinlikle Katılmiyorum, $2=$ Katılmıyorum, $3=$ Kararsızım, $4=$ Katılıyorum, $5=$ Kesinlik Katıliyorum anlamindadir. (iii) Friedman çift yönlü Anova testine göre $\chi^{2}=23,118$; $p<0,05$ sonuçlar istatistiksel bakımdan anlamlıdır. Ort: Ortalama, SS: Standart Sapma

Öznel normlar alt boyutuna ilişkin tanımlayıcı istatistikler incelendiğinde, ortalaması en yüksek olan maddenin 3,24 ile "Satın alma davranışımda etkisi olan insanlar, sosyal ağ ve sosyal medya sitelerinde viral olarak pazarlanan mamül ve hizmetleri almam konusunda beni cesaretlendirebilir." ve ortalamas1 2,99 ile en düşük olan maddenin ise "Meslektaşlarım sosyal ağ ve sosyal medyada tartış1lan ve viral olarak pazarlanan ürün ve hizmetleri satın almam gerektiğini düşünmektedirler." Olduğu görülmektedir. Alt boyuta ilişkin güvenilirlik analizi ile elde edilen Cronbach's Alpha değeri 0,78 olarak hesaplanmıştır. Bu sonuca göre "Öznel Normlar Boyutu"nda elde edilen sonuçların yüksek güvenilir olduğu gözlemlenmektedir (Tavşancıl, 2006).

Tablo 8: Kişisel Algılanan Risk Alt Boyutuna İlişkin Tanımlayıcı İstatistikler

Faktör/Alt Boyut ve Maddeler

Ort. SS

\section{Kişisel Algılanan Risk (KAR)}

Viral olarak sosyal ağ ve sosyal medya sitelerinde pazarlanan mamül ve hizmetlerin riskli $3,09 \quad 1,26$ olduğuna inanmaktayım. Çünkü bu başkalarının benim daha düşük seviyede bir tüketici olduğumu düşünmelerine neden olabilir.

Viral olarak sosyal ăg ve sosyal medya sitelerinde pazarlanan mamül- hizmetlerin riskli olduğuna $2,98 \quad 1,11$ inanmaktayım. Çünkü bu yolla gönderilen ürün ve hizmetler benim kişisel imajıma uyum göstermemektedir.

Viral olarak sosyal ağ ve sosyal medya sitelerinde pazarlanan mamül ve hizmetleri satın almam $\quad 3,11 \quad 1,18$ paramı kötü bir şekilde harcadığımı düşünmeme neden olabilir.

\begin{tabular}{lc}
\hline Genel & $3,06 \quad 0,96$ \\
Cronbach's Alpha & 0,74 \\
\hline
\end{tabular}

Not: (i) $n=475$. (ii) Ölçekte 1= Kesinlikle Katılmıyorum, 2= Katılmıyorum, 3= Kararsızım, 4= Katılıyorum, 5= Kesinlik Katılıyorum anlamındadır. (iii) Friedman çift yönlü Anova testine göre $\chi^{2}=6,612 ; p<0,05$ sonuçlar istatistiksel bakımdan anlamlıdır. Ort: Ortalama, SS: Standart Sapma 
Kişisel algılana risk alt boyutuna ilişkin tanımlayıcı istatistikler incelendiğinde, ortalaması en yüksek olan maddenin 3,11 ile "Viral olarak sosyal ağ ve sosyal medya sitelerinde pazarlanan mamül ve hizmetleri satın almam paramı kötü bir şekilde harcadığımı düşünmeme neden olabilir." ve ortalaması 2,98 ile en düşük olan maddenin ise "Viral olarak sosyal ağ ve sosyal medya sitelerinde pazarlanan ürün- hizmetlerin riskli olduğuna inanmaktayım. Çünkü bu yolla gönderilen mamül ve hizmetler benim kişisel imajıma uyum göstermemektedir.” olduğu belirlenmiş̧ir. Alt boyuta ilişkin güvenilirlik analizi ile elde edilen Cronbach's Alpha değeri 0,74 olarak hesaplanmıştır. Bu sonuca göre "Kişisel Algılanan Risk Boyutu"nda elde edilen sonuçların güvenilir olduğu gözlemlenmektedir (Tavşanc1l, 2006).

Tablo 9: Sosyal Bütünleşme Alt Boyutuna İlişkin Tanımlayıcı İstatistikler

\section{Faktör/Alt Boyut ve Maddeler}

Ort. SS

\section{Sosyal Bütünleşme (SB)}

Tüketicilerin sosyal ağ ve sosyal medyada viral olarak pazarlanan mamül ve hizmetlerle ilgili $\quad 2,82 \quad 1,17$ olarak şeffaf olduklarını düşünmekteyim.

Sosyal ağ ve sosyal medyada viral olarak pazarlanan mamül ve hizmetlere ilişkin görsellerin $\quad 2,75 \quad 1,18$ hileli olmadığını düşünmekteyim.

Sosyal ağ ve sosyal medyada viral olarak pazarlanan mamül ve hizmetlere ilişkin yorumların- $\quad 2,86 \quad 1,18$ görüşlerin hileli olmadığını düşünmekteyim.

\begin{tabular}{lc}
\hline Genel & 2,81 \\
Cronbach's Alpha & 0,96 \\
\hline
\end{tabular}

Not: (i) n=475. (ii) Ölçekte 1= Kesinlikle Katılmıyorum, 2= Katılmıyorum, 3= Kararsızım, 4= Katılıyorum, 5= Kesinlik Katılıyorum anlamındadır. (iii) Friedman çift yönlü Anova testine göre $\chi^{2}=3,746$; $p<0,05$ sonuçlar istatistiksel bakımdan anlamlıdır. Ort: Ortalama, SS: Standart Sapma

Sosyal bütünleşme alt boyutuna ilişkin tanımlayıcı istatistikler incelendiğinde, ortalaması en yüksek olan maddenin 2,86 ile "Sosyal ağ ve sosyal medyada viral olarak pazarlanan mamül ve hizmetlere ilişkin yorumların-görüşlerin hileli olmadığını düşünmekteyim." ve ortalaması 2,75 ile en düşük olan maddenin ise "Sosyal ağ ve sosyal medyada viral olarak pazarlanan mamül ve hizmetlere ilişkin görsellerin hileli olmadığını düşünmekteyim." olduğu görülmektedir. Alt boyuta ilişkin güvenilirlik analizi ile elde edilen Cronbach's alpha değeri 0,74 olarak hesaplanmıştır. Bu sonuca göre "Sosyal Bütünleşme Boyutu"nda elde edilen sonuçların güvenilir olduğu görülmektedir (Tavşanc1l, 2006).

Tablo 10: Argüman-Kaynak Kalitesi Alt Boyutuna İlişkin Tanımlayıcı İstatistikler

\section{Faktör/Alt Boyut ve Maddeler}

Ort. SS

\section{Argüman-Kaynak Kalitesi (AK)}

İnsanların paylaştığı yeni deneyimleri görmek için sosyal ă̆ ve sosyal medya kullanmayı severim.

Mamül-hizmetleri almadan önce viral yoldan pazarlanan ürünlerle ilgili olarak sosyal ağ ve sosyal medyada yer alan argümanları (kaynakları) okumak kendimi daha güvende hissettirir.

Eğer sosyal ağ ve soayal medyada almayı düşündüğüm mamül-hizmetle ilgili olarak bir kanıt $\quad 3,42 \quad 1,27$ okumadıysam, satın alma kararım konusunda endişe duyarım.

\begin{tabular}{lc}
\hline Genel & $3,46 \quad 0,90$ \\
Cronbach's Alpha & 0,53 \\
\hline
\end{tabular}


Not: (i) $n=475$. (ii) Ölçekte 1= Kesinlikle Katılmıyorum, 2= Katılmıyorum, 3= Kararsızım, 4= Katılıyorum, 5= Kesinlik Katılıyorum anlamındadır. (iii) Friedman çift yönlü Anova testine göre $\chi^{2}=11$,484; p<0,05 sonuçlar istatistiksel bakımdan anlamlıdır. Ort: Ortalama, SS: Standart Sapma

Argüman-kaynak kalitesi alt boyutuna ilişkin tanımlayıcı istatistikler incelendiğinde, ortalaması en yüksek olan maddenin 3,59 ile "İnsanların paylaştığı yeni deneyimleri görmek için sosyal ağ ve sosyal medya kullanmayı severim." ve ortalaması 3,37 ile en düşük olan maddenin ise "Mamül-hizmetleri almadan önce viral yoldan pazarlanan ürünlerle ilgili olarak sosyal ağ ve medyada yer alan argümanları (kaynakları) okumak kendimi daha güvende hissettirir." olduğu belirlenmiştir. Alt boyuta ilişkin güvenilirlik analizi ile elde edilen Cronbach's alpha değeri 0,53 olarak hesaplanmıştır. Bu sonuca göre "Argüman-Kaynak Kalitesi Boyutu"nda elde edilen sonuçların düşük güvenilir olduğu söylenebilir (Tavşancıl, 2006).

Tablo 11: Sosyal Ağ ve Soyal Medya Sitelerinde Yer Alan Viral Pazarlama Ölçeği Alt Boyutlarına Ait Korelasyon Analizi Sonuçları

\begin{tabular}{|c|c|c|c|c|c|c|c|}
\hline & $\mathrm{DN}$ & $\mathrm{T}$ & AR & ÖN & KAR & SB & AK \\
\hline DN & 1 & $0,729 *$ & $0,225^{*}$ & $0,643^{*}$ & $0,527^{*}$ & $0,593^{*}$ & $0,341^{*}$ \\
\hline $\mathrm{T}$ & - & 1 & $0,236^{*}$ & $0,605^{*}$ & $0,381^{*}$ & $0,620^{*}$ & $0,446 *$ \\
\hline AR & - & - & 1 & $0,341^{*}$ & $0,474^{*}$ & $0,222^{*}$ & $0,284^{*}$ \\
\hline ÖN & - & - & - & 1 & $0,551^{*}$ & $0,537^{*}$ & 0,301 * \\
\hline KAR & - & - & - & - & 1 & $0,354^{*}$ & $0,162^{*}$ \\
\hline SB & - & - & - & - & - & 1 & $0,218^{*}$ \\
\hline AK & - & - & - & - & - & - & 1 \\
\hline
\end{tabular}

$* p<0,001$

Tablo 11'deki sonuçlara göre, davranışsal niyet ile sosyal ağ ve sosyal medya sitelerinde yer alan viral pazarlama ölçeğine ait diğer alt boyutlar arasında pozitif ve istatistiksel olarak anlamlı bir ilişki vardır $(\mathrm{p}<0,05)$. Analiz sonuçları incelendiğinde, davranışsal niyet ile bilgi kullanımına ilişkin tutum boyutu arasında istatistiksel olarak pozitif ve yüksek bir ilişkinin olduğu, ayrıca ankete katılanların davranışsal niyet algıları ile sosyal ağ ve sosyal medya sitelerinde yer alan viral pazarlama ölçeğine ait diğer alt boyutlar arasında bilgi kullanımına ilişkin tutum algısının en yüksek anlamlı ilişkiye sahip olduğu görülmektedir $(r=0,729)$. Öznel normalar, kişisel algılanan risk ve sosyal bütünleşme alt boyutları ile davranışsal niyet arasında pozitif, orta düzeyli ve istatistiksel olarak anlamlı bir ilişki vardır $(p<0,05)$. Algılanan risk ve argüman-kaynak kalitesi alt boyutları ile davranışsal niyet arasında ise pozitif ve istatistiksel olarak anlamlı ancak diğer boyutlara göre düşük düzeyli bir ilişki mevcuttur $(\mathrm{p}<0,05)$.

Tablo 12: Araştırmada Ele Alınan Araştırma Modeline İlişsin Aracılık Etkilerine Ait Analiz Sonuçları

\begin{tabular}{lllllllllll}
\hline ilişki Yolları & $B$ & $S H$ & 6 & $p$ & $F$ & $R^{2}$
\end{tabular}

(Model 1)

\begin{tabular}{|c|c|c|c|c|c|c|c|}
\hline $\mathrm{AK} \rightarrow \mathrm{T}$ & & 0,394 & 0,036 & 0,446 & $<0,001$ & $117,766^{*}$ & 0,199 \\
\hline $\mathrm{AK} \rightarrow \mathrm{DN}$ & & 0,321 & 0,041 & 0,341 & $<0,001$ & $62,248^{*}$ & 0,116 \\
\hline $\mathrm{AK} \rightarrow(\mathrm{T}) \rightarrow \mathrm{DN}$ & $\mathrm{T} \rightarrow \mathrm{DN}$ & 0,770 & 0,038 & 0,721 & $<0,001$ & $269,257 *$ & 0,532 \\
\hline
\end{tabular}




\section{(Model 2)}

\begin{tabular}{llllllll} 
SB $\rightarrow$ ÖN & & 0,521 & 0,038 & 0,537 & $<0,001$ & $192,459 *$ & 0,289 \\
SB $\rightarrow$ DN & & 0,528 & 0,033 & 0,593 & $<0,001$ & $257,343^{*}$ & 0,352 \\
\hline \multirow{2}{*}{ SB $\rightarrow$ (ÖN) $\rightarrow$ DN } & ÖN $\rightarrow$ DN & 0,418 & 0,035 & 0,456 & $<0,001$ & & \\
& SB $\rightarrow$ DN & 0,310 & 0,034 & 0,348 & $<0,001$ & $236,050^{*}$ & 0,500 \\
\hline
\end{tabular}

(Model 3)

$\begin{array}{lllllll}A R \rightarrow D N & 0,202 & 0,040 & 0,225 & <0,001 & 25,184 * & 0,050\end{array}$

${ }^{*}{ }_{p}<0,001$, B: Regresyon Katsayısı, SH: Standart Hata, B: Standartlaştırlmış Regresyon Katsayısı, F: Model Anlamlılık Testi, R2: Açıklayıclık Katsayısı, AK: Argüman-Kaynak Kalitesi, T: Bilgi Kullanımına İlişkin Tutum, DN: Davranışsal Niyet, SB: Sosyal Bütünleşme, ÖN: Öznel Normlar, AR: Argüman-Kaynak Kalitesi

Tablo 12'de yer alan Model 1 incelendiğinde, Baron ve Kenny'in (1986) şartlarının sağladığı görülmektedir. İlk şart, bağımsız değişkenle (Argüman Kaynak Kalitesi) aracı değişken (Bilgi Kullanımına İlişkin Tutum) arasında anlamlı bir etkinin olmasıydı ve bu gerçekleşmiştir $(\beta=0,446, p<0,001)$. İkinci şart, bağımsız değişkenin (Argüman Kaynak Kalitesi) bağımlı değişken (Davranışsal Niyet) üzerinde anlamlı bir etkisinin olmasıydı. Bu etki istatistiksel olarak anlamlı çıkmıştır $(\beta=0,341, \mathrm{p}<0,001)$. Son olarak, bağımsız değişken (Argüman Kaynak Kalitesi) ile aracı değişken (Bilgi Kullanımına İlişkin Tutum) birlikte modele dâhil edilip bağımlı değişken (Davranışsal Niyet) açıklanmaya çalışılmıştır. Bu adımdan sonra, ikinci adımdaki anlamlı etkinin anlamsız olması (tam aracı etki) veya etkisinin azalması (kısmi aracı etki) aracı etkinin yer aldığı modelde diğer boyutlara etkisi noktasında bize ipucu verecektir. Üçüncü adımı incelendiğimizde Argüman Kaynak Kalitesi ile Bilgi kullanımına ílişkin tutum, arasındaki ilişki (ikinci adımla karşılaştırıldığında) anlamlıdır. Ancak etki düzeyinin azaldığını görebiliriz $(\beta=0,019, p<0,001)$. Bu durum, argüman-kaynak kalitesi ile davranışsal niyet boyutu arasında Bilgi kullanımına ilişkin tutum kısmi aracı etkiye sahip olduğunu göstermektedir. Fakat, bu aracı etkiden söz etmek için yeterli değildir. Kesin bir sonuca ulaşmak için, Beta $(\beta)$ değerlerindeki azalma miktarının anlamlılığının tespit edilmesi gerekir. Beta değerlerindeki azalma miktarının anlamlılık düzeyi ise Sobel Testi kullanılarak yapılmıştır. Sobel Testi sonuçları, $Z=9,831, p<0,001$ şeklinde gerçekleşmiştir. Bu sonuçlara göre, değerlerinde meydana gelen azalma anlamlıdır. Bilgi kullanımına ilişkin tutumun, argüman-kaynak kalitesi ile davranışsal niyet boyutu arasında kısmi aracı etkiye sahip olduğu söylenebilir. Bu doğrultuda, H1 kabul edilmiştir.

Model 2 incelendiğinde, Baron ve Kenny'in (1986) şartlarının gerçekleştiği görülmektedir. İlk şart, bağımsız değişkenle (Sosyal bütünleşme) aracı değişken (Öznel Norm) arasında anlamlı bir etkinin olmasıydı ve bu gerçekleşmiştir $(\beta=0,537, p<0,001)$ İkinci şart ise bağımsız değişkenin (Sosyal bütünleşme) bağımlı değişken (Davranışsal Niyet) üzerinde anlamlı bir etkisinin olmasıydı. Bu etki istatistiksel olarak anlamlı çıkmıştır ( $\beta=0,593, p<0,001)$ Son olarak, bağımsız değişken (Sosyal Bütünleşme) ile aracı değişken (Öznel Norm) birlikte modele dâhil edilmiş ve bağımlı değiş̧ken (Davranışsal Niyet) açılanmaya çalışılmıştır. Bu aşamadan sonra, ikinci adımdaki anlamlı etkinin anlamsız olması (tam aracı etki) veya etki düzeyinin zayıflaması (kısmi aracı etki) aracı etkinin varlığı noktasında bize ipucu verecektir. Üçüncü adım incelendiğinde Sosyal bütünleşme ile Öznel Norm, arasındaki ilişki (ikinci adımla karşılaştırıldığında) anlamlıdır. Ancak etki düzeyinin azaldığını görebiliriz $(\beta=0,348, p<0,001)$ Bu durum, sosyal bütünleme ile davranışsal niyet boyutu arasında öznel normun kısmi aracı etkiye sahip olduğunu sonucunu doğurabilir. Ancak, bu aracı etkiden söz etmek için yeterli değildir. Kesin sonuca ulaşmak için, Beta $(\beta)$ değerlerindeki azalma miktarının anlamlılığının tespit edilmesi gerekir. Beta değerlerindeki azalma miktarının anlamlılık düzeyi ise Sobel Testi kullanılarak yapılmıştır. Sobel Testi sonuçları, $Z=11,002, p<0,001$ şeklinde gerçekleşmiştir. Bu sonuçlara göre, değerlerinde meydana gelen azalma anlamlıdır. Öznel normun, sosyal bütünleşme ile davranışsal niyet boyutu arasında kısmi aracı etkiye sahip olduğu söylenebilir. Bu doğrultuda, $\mathrm{H} 2$ kabul edilmiştir. 
Model 3 incelendiğinde, algılanan riskin davranışsal niyet üzerindeki etkisinin istatistiksel olarak anlamlı olduğu görülmektedir $(\beta=0,225, \mathrm{p}<0.001)$. Sosyal ağ ve sitelerini kullanan kullanıcıların, bu sitelerde üzerinden satın alacakları ürünlere ilişkin algıladıkları riskin satın almayı düşündükleri ürünler hakkındaki niyetlerini pozitif etkilediği, ancak bu etkinin anlamlı olsa bile düşük düzeyde kaldığı tespit edilmiştir. Bununla birlikte, elde edilen sonuçlar Gunawan ve Huarng (2015) tarafindan elde edilen sonuçlar ile benzerlik göstermektedir. Gunawan ve Huarng (2015) yaptıkları yapısal eşitlik modellemesi ile davranışsal niyet üzerine bilgi kullanımına ilişkin tutumun etkisi $(\beta=0,40)$, öznel normların etkisinin $(\beta=0,32)$ ve algılanan riskin etkisinin $(\beta=-0,19)$ olduğunu belirlemişlerdir.
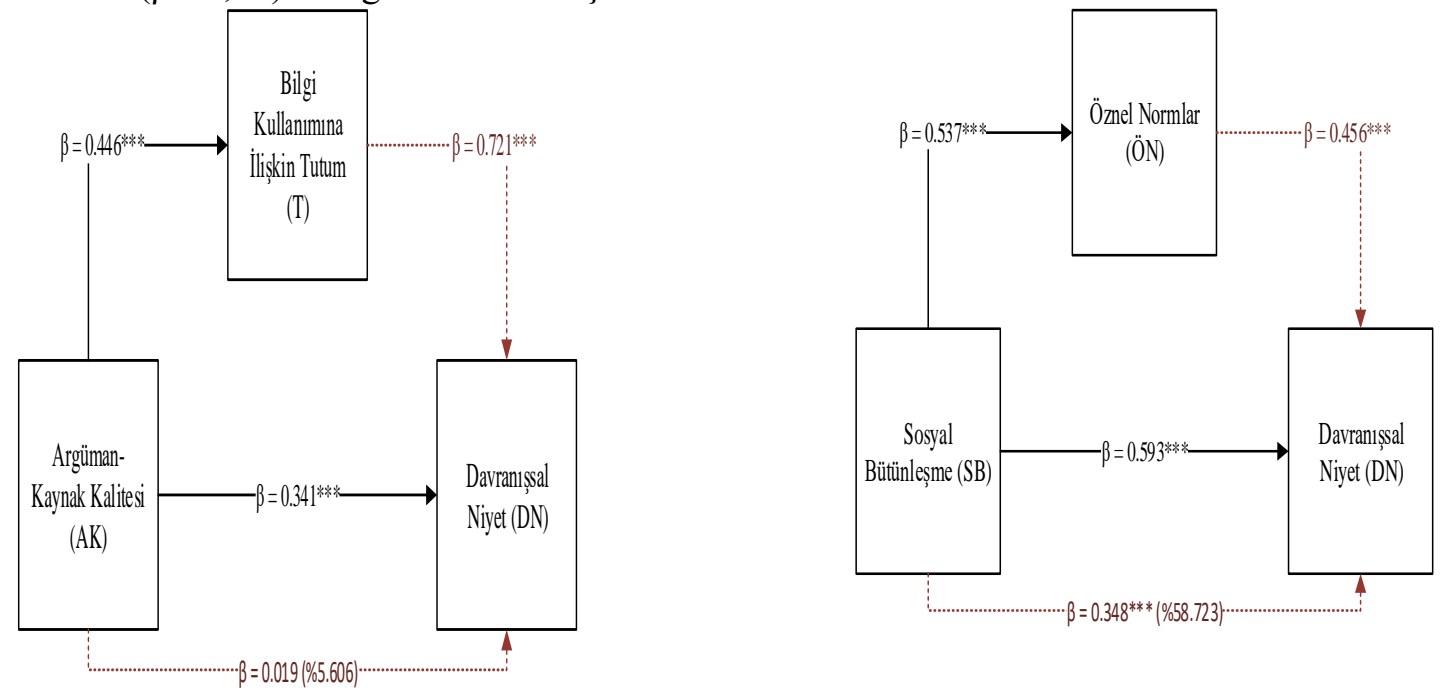

Şekil 2: Bilgi Kullanımına İliş̧kin Tutum (T) Boyutunun Algılanan Risk (AR) ile Davranışsal Niyet (DN) Arasındaki Aracılık ve Öznel Norm (ÖN) Boyutunun Sosyal Bütünleşme (SB) ile Davranışsal Niyet (DN) Arasındaki Aracılık Rolüne İlişkin Elde Edilen Direk ve Direkt Olmayan Standartlaştırılmış Regresyon Katsayıları

Sosyal Ağ ve Medya Sitelerinde Viral Pazarlama ölçeği alt boyutlarının cinsiyete göre farklılıkları için yapılan analiz sonuçları Tablo 13' de yer almaktadır.

Tablo 13: Katılımcıların Cinsiyetlerine Göre Sosyal Ă̆ ve Medya Sitelerinde Viral Pazarlama Uygulamaları Ölçeği Alt Boyutlarının İçin Yapılan Farklıık Analizi Sonuçları

\begin{tabular}{cccccccc}
\hline & \multicolumn{3}{c}{ Kadın $(\mathbf{n = 2 3 6 )}$} & \multicolumn{3}{c}{ Erkek $(\mathbf{n = 2 4 0})$} & \multirow{2}{*}{ Faktörler } \\
\cline { 2 - 6 } & Ort & SS & Med & Ort & SS & Med & p \\
\hline DN & 3,02 & 0,83 & 3,00 & 3,05 & 0,87 & 3,00 & 0,590 \\
AK & 3,50 & 0,89 & 3,67 & 3,43 & 0,91 & 3,67 & 0,421 \\
T & 3,07 & 0,80 & 3,00 & 3,07 & 0,79 & 3,00 & 0,909 \\
SB & 2,83 & 0,90 & 3,00 & 2,80 & 1,01 & 2,67 & 0,664 \\
ÖN & 3,13 & 0,94 & 3,25 & 3,06 & 0,91 & 3,25 & 0,593 \\
AR & 3,44 & 0,96 & 3,50 & 3,21 & 0,92 & 3,25 & $0,011 *$ \\
KAR & 3,06 & 1,01 & 3,00 & 3,07 & 0,92 & 3,00 & 0,764
\end{tabular}


p: Mann Whitney-U testine ilişkin istatistiksel anlamlılık değeri, *p<0,05, DN: Davranışsal Niyet, AK: ArgümanKaynak Kalitesi, T: Bilgi Kullanımına İlişkin Tutum, SB: Sosyal Bütünleşme, ÖN: Öznel Normlar, AR: Algılanan Risk, KAR: Kişisel Algılanan Risk, Ort: Ortalama, SS: Standart Sapma, Med: Medyan

Tablo 13'de katılımcıların cinsiyetlerine göre Sosyal ağ ve sitelerinde viral pazarlama uygulamaları ölçeği alt boyutlarının farklılıkları Mann Whitney-U testi ile araştırılmıştır. Elde edilen bulgulara göre, araştırmaya katılanların argüman kaynak kalitesi algıları cinsiyete göre farklılık göstermektedir $(p=0,011<0,05)$. Kadın bireylerin argüman kaynak kalitesi algısı, erkeklerden istatistiksel olarak anlamlı bir şekilde daha yüksektir. Diğer alt boyutlara ilişkin algılar ise katılımcıların cinsiyetlerine göre istatistiksel olarak anlamlı bir farklılık göstermemektedir ( $>0,05)$. Tablo 13'de elde edilen bulguların grafiksel gösterimleri ve elde edilen anlamlılık değerleri (p) Şekil 3'de verilmiştir.

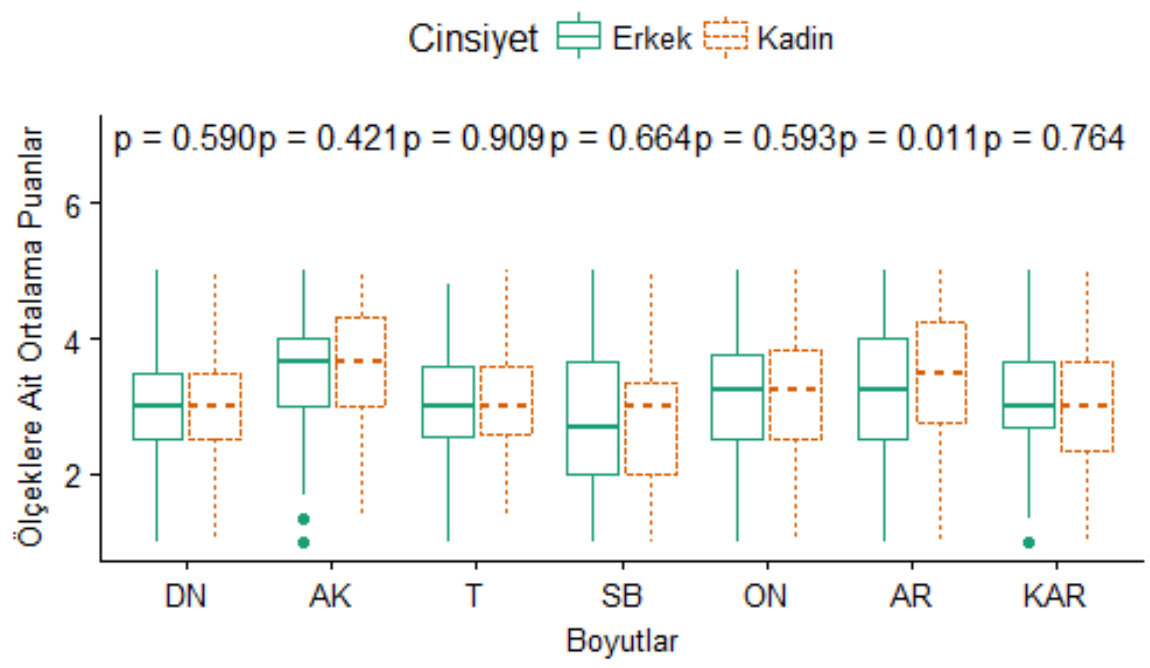

\section{Şekil 3: Katılımcıların Cinsiyetlerine Göre Sosyal Ăg ve Sitelerinde Viral Pazarlama Uygulamaları Ölçeği Alt Boyutlarına İliş̧kin Elde Edilen Ortalamaların Dağılımları}

Bununla birlikte, elde edilen sonuçlar Gunawan ve Huarng (2015) tarafindan elde edilen sonuçlar ile benzerlik göstermektedir. Gunawan ve Huarng (2015) yaptıkları yapısal eşitlik modellemesi ile davranışsal niyet üzerine bilgi kullanımına ilişkin tutumun etkisi $(\beta=0,40)$, öznel normların etkisinin $(\beta=0.32)$ ve algılanan riskin etkisinin $(\beta=-0,19)$ olduğunu belirlemişlerdir.

\section{SONUÇ}

Sosyal ağ ve sosyal medya platformları üzerinden günümüzde kullanıc1lar birbirleriyle kolay, hızl, eğlenceli ve etkili bir iletişim kurabilmektedirler. Bu platformlar üzerinden gerçekleştirilen iletişimlerde, tüketicilerin satın alma kararlarını etkileyen birçok faktör olmasına rağmen, tüketicilerin en çok etkilendikleri kullandıkları ürünler hakkında yaptıkları yorumlardır. Kullanılan ürünler hakkında herhangi bir olumlu veya olumsuz yorum tüketiciler arasında hızlıca yayılır. İşletmelerin bu durumun farkında olması ve maliyet bakımından da yöntemin avantajlar içermesi, viral pazarlama uygulamalarının sosyal ağ ve sosyal medya sitelerinde etkin bir şekilde kullanmasına neden olmuştur.

İstanbul'da ikamet eden tüketiciler üzerine yapılan bu çalışmada, sosyal ağ ve medya sitelerinde viral pazarlamanın etkisinin belirlenmesi amaçlanmıştır. Araştırma için sosyal medya kullanıcısı 476 üzerinde anket gerçekleştirilmiştir. Bu amaç doğrultusunda sosyal ağ kullanan tüketicilerin özellikle bilgi kullanımına ilişkin tutumlarını, argüman kalitesine güvenini, sosyal bütünleşme ve algılanan risklerin davranışsal niyet üzerinde ne derece etkili olduğunu sonucunu elde edecek ifadeler araştırmaya katılanlara sorulmuştur. Yapılan çalışmada argüman-kaynak kalitesini, bilgi kullanımına ilişkin tutumu aracı etki kılarak davranışsal niyet üzerinde etkisi analiz edilmiştir. Bunun yanı sıra sosyal bütünleşmeyi, öznel normları aracı etki kılarak davranışsal niyet üzerine etkisi analiz edilmiştir. Ayrıca cinsiyet faktörünün ölçeğin alt boyutları üzerinde farklılığın olup olmadığı incelenmiştir.

Bu doğrultuda sosyal ağ ve medya sitelerin de yer alan viral pazarlama uygulamalarının alt boyutlarının (Bilgi Kullanımına İlişkin Tutum, Algılanan Risk, Öznel Normlar, Kişisel Algılanan Risk, Sosyal Bütünleşme) 
Davranışsal Niyet üzerine direk ve aracı etkisini ölçmek amacıyla yapılan bu çalışmadan elde edilen sonuçlar aşağıldaki gibidir.

- Cinsiyete göre alt boyutların farkl11ık göstermesi incelendiğinde edilen bulgulara göre, araştırmaya katılanların argüman kaynak kalitesi algıları cinsiyete göre farklılık göstermektedir. Diğer alt boyutlara ilişkin algının cinsiyete göre anlamlı bir farklılık göstermemektedir.

- Sosyal ağ ve sosyal medya sitelerinde yer alan viral pazarlama ölçeğinin alt boyutları tek tek ele alındığında, tüm alt boyutlar ile davranışsal niyet arasında kurulacak tüm modellerin istatistiksel olarak anlamlı olduğu görülmüştür.

- Argüman kaynak kalitesi ile davranışsal niyet alt boyutu arasında bilgi kullanımına ilişkin tutumun kısmi aracı etkiye sahip olduğu görülmüştür.

- Sosyal bütünleşme ile davranışsal niyet alt boyutu arasında öznel normların kısmi aracı etkiye sahip olduğu görülmüştür.

- Sosyal ağ ve sitelerini kullanan kullanıcıların, bu sitelerde üzerinden satın alacakları ürünlere iliş̧in algıladıkları riskin satın almayı düşündükleri ürünler hakkındaki niyetlerini pozitif etkilediği, ancak bu etkinin anlamlı olsa bile düşük düzeyde kaldığı tespit edilmiştir.

- Sosyal ağ ve sosyal medya sitelerinde yer alan viral pazarlama ölçeği alt boyutlarının davranışsal niyet algısı üzerine birlikte etkileri ele alındığında, kurulacak modelin istatistiksel olarak anlamlı olduğu belirlenmiştir. Bağımsız değişken incelendiğinde, argüman-kaynak kalitesi algısının tek başına davranışsal niyet üzerine anlamlı etkisi olmasına rağmen diğer alt boyutlar ile birlikte kullanıldığında istatistiksel olarak anlamlı bir etkiye sahip olmadığı görülmüş̧ür.

Sosyal ağ ve sosyal medya sitelerinde yer alan viral pazarlama ölçeğinin alt boyutlarında davranışsal niyet algısını anlamlı şekilde açıklayabilecek en iyi alt boyutun bilgi kullanımına ilişkin tutum algısının olduğu, bununla birlikte algılanan risk algısı ve argüman-kaynak kalitesi alt boyutlarının davranışsal niyet algısını açıklamakta yetersiz kaldığ 1 görülmüş̧ür.

Yapılan korelasyon analizinde, sosyal ağ ve medya sitelerinde yer alan viral pazarlama ölçeğinin alt boyutlarında Davranışsal Niyet Algısı üzerinde anlamlı bir ilişki olduğu görülmektedir. Bu sonuç, sosyal ağ ve sosyal medya sitelerinde yer alan viral pazarlama ölçeğinin alt boyutlarının (Bilgi Kullanımına İlişkin Tutum, Algılanan Risk, Öznel Normlar, Kişisel Algılanan Risk, Sosyal Bütünleşme) Davranışsal Niyet üzerinde etkisi olduğunu göstermektedir.

Çalışmadan elde edilen sonuçlarla ilgili şu genel değerlendirmeler yapılabilir: $\mathrm{Bu}$ çalışmanın sadece İstanbul'da yaşayan tüketiciler üzerinde yapılması, çalışmada önemli bir kısıttır. Diğer yapılacak çalışmalarda farklı iller ve örneklem grupları üzerinde araştırmanın yürütülmesi literatüre önemli bir katkı sağlayacaktır.

Çalışmayı bütün olarak incelediğimizde, elde edilen sonuçların genel algıyı desteklediği ve literatürde bu alanda yapılan çalışmalarla benzerlik gösterdiği görülmektedir. Bu doğrultuda çalışmadan elde edilen sonuçlar, sosyal medyada yer alan viral pazarlama uygulamalarının önemini tekrar vurgulamaktadır. 


\section{KAYNAKÇA}

Aksoy, R. (2009). İnternet ortamında pazarlama, Ankara: Seçkin Yayıncılık.

Aldhafferi, N., Wat son, C., ve Sajeev, A. (2013). Personal information privacy settings of online social networks and their suitability for mobile internet devices. arXiv preprint arXiv:1305.2770.

Argan, M., Argan, T. (2006). Viral Pazarlama veya İnternet Üzerinde Ağızdan Ağıza Reklam: Kuramsal Bir Çerçeve, Pamukkale Üniversitesi Sosyal Bilimler Dergisi, 231-246

Balcı, A. (2007). Sosyal bilimlerde araştırma Yöntem, Teknik ve İlkeler, Ankara: Pegem A Yayıncılık.

Banna, K.J. (2000). It's catching (viral marketing). Mediaweek 10(23),20.

Bostancı, M. (2010). Sosyal Medyanın Gelişimi ve İletişim Fakültesi Öğrencilerinin Sosyal Medya Kullanım Alışkanlıkları. Yayımlanmamış Yüksek Lisans Tezi. Erciyes Üniversitesi, Sosyal Bilimler Enstitüsü, Kayseri.

Brown, M. R., Bhadury, R. K., ve Pope, N. K. L. (2010). The İmpact Of Comedic Violence On Viral Advertising Effectiveness. Journal of Advertising, 39(1), 49-66.

Cevher, M. F. (2014). Viral Pazarlamanın Tüketicilerin Satın Alma Kararları Üzerine Etkisi. , Yüksek Lisans Tezi. Fırat Üniversitesi, Sosyal Bilimler Enstitüsü İşletme Anabilim Dalı, Elazı̆̆.

Coney, K. A., Best, R., ve Hawkins, D. (2001). Consumer Behavior: Building Marketing Strategy, New York :McGrawHill Book Company.

Çoşkunkurt, Y. (2013). Sosyal Medya Kullanımının Kurumsal Yenilikçi İtibar Üzerindeki Etkisi Üzerine Bir Araştırma. Doktora Tezi, Marmara Üniversitesi, Sosyal Bilimler Enstitüsü, İstanbul.

Eru, O. (2013). Süpermarket Sektöründeki Mobil Pazarlama Uygulamalarının Tüketici Davranışlarına Etkisi: Aydın örneği. Doktora Tezi, Adnan Menderes Üniversitesi, Sosyal Bilimler Enstitüsü, Aydın.

Eryılmaz, B. (2014). Sosyal Medya Kullanımının Müşteri Tercihleri Üzerine Etkileri: Konaklama İşletmelerinde Bir İnceleme. Doktora Tezi, Sakarya Üniversitesi, Sosyal Bilimler Enstitüsü, Sakarya.

Eldem, Ü. (2009). Bilinçaltı Reklamcılık ve Tüketici Davranışları Üzerindeki Etkisi. Yüksek Lisans Tezi, Maltepe Üniversitesi, Sosyal Bilimler Enstitüsü, İstanbul.

Genç, Y. E. (2015). Üniversite Öğrencilerinin Sosyal Medya Kullanımı Ve Bunun Satın Alma Davranışlarına Etkisi. Yüksek Lisans Tezi, İzmir Katip Çelebi Üniversitesi, Sosyal Bilimler Enstitüsü, İzmir.

Glen, L. (1993). Design and Marketing of New Products, Prentice Hall, pp. 1-7.

Gunawan, D. D., Huarng, K.-H. (2015). Viral effects of social network and media on consumers' purchase intention, Journal of Business Research, 68(11), 2237-2241.

Gültaş, P., Yıldırım, Y. (2016). İnternetten Alışverişte Tüketici Davranışını Etkileyen Demografik Faktörler, Dicle Üniversitesi İktisadi ve İdari Bilimler Fakültesi Dergisi, 6(10), 32-51.

Hazar, M. (2011). Sosyal Medya Bagımlılıgı-Bir Alan Çalışması, Iletisim Kuram ve Arastirma Dergisi, (32).

Lam, D., Mizerski, D. (2005). The Effects of Locus of Control on Word of Mouth Communication, Journal of Marketing Communications, 11(3), 215-228.

Kurcova, İ. (2002). İnternette Pazarlama, İstanbul: Beta Yayınları.

Mark, W. (2011). Essentials of marketing management, New York: McGraw-Hill/Irwin, pp. 20-25.

Meltem, Ö. (2012). Öğrencilerin Sosyal Medya Kullanımını ve Üniversitelerde Dijital Pazarlama İletişimi Uygulamalarını Belirlemeye Yönelik Bir Çalışma, Beykent University Institute of Social Sciences. Master Thesis, İstanbul.

Nacak, O. (2012). Bilinçaltı Reklam Uygulamaları: Galatasaray Üniversitesi Öğrencileri Üzerine Bir Uygulama. Yüksek Lisans Tezi, Süleyman Demirel Üniversitesi, Sosyal Bilimler Enstitüsü, Isparta.

Özcan, S. O. (2010). İnternet Pazarlama Faaliyetlerinde Tüketici Satın Alma Karar Süreci, İnternet Uygulamaları ve Yönetimi Dergisi, (2), 29-39.

Parlak, F. (2015). Sosyal Medya ve Tüketici Satın Alma Karar Sürecine Etkileri: Nitel Bir Uygulama. Yüksek Lisans Tezi, Dumlupınar Üniversitesi, Sosyal Bilimler Enstitüsü, Kütahya.

Rosen, E. (2000). The Anatomy of Buzz: How to create word-of-mouth marketing, Marketing Management, 9(4), 62.

Serpil, Ü. (2011). Viral Pazarlamanın Sosyal Paylaşım Sitelerine Üye Olan Kullanıcılar Üzerindeki Etkisini İnceleyen Pilot Bir Çalışma, Öneri Dergisi, 9(36), 73-86.

Schiffman, L., O’cass, A., Poladino, A., Carlson, J.,(2014). Consumer Behavior, Australia: Group Ply Ltd.

Skrob, J.-R. (2005). Open Source And Viral Marketing, Austria: University of Applied Science Kufstein.

Sim, Ş., Toprak, M, (2012). Sinemayı Hayata Yaklaştırmak: Sahte Belgesel (Mockumentary) Filmler, ş1-10.

Solmaz, I. (2014). Nöropazarlama Faaliyetlerinde Bilinçaltı Reklamcılık ve Tüketici Algısı Üzerindeki Etkisi. Yüksek Lisans Tezi. Gediz Üniversitesi, Sosyal Bilimler Enstitüsü, İzmir.

Taş, M. K. (2014). Pazarlama İletişiminde Sosyal Medya Kullanımı: Sigorta Pazarına Bir Uygulama. Yüksek Lisans Tezi, İstanbul Ticaret Üniversitesi, Sosyal Bilimler Enstitüsü, İstanbul.

Ural, A., ve Kılıç, İ. (2006). Bilimsel araştırma süreci ve SPSS ile veri analizi: SPSS 10.0-12.0 for windows, Ankara: Detay yayıncilik.

Wilson, R. F. (2000). The six simple principles of viral marketing, Web marketing today, 70(1), 232.

TUIKK. (2017). "Nüfus İstatistikleri Veri Tabanı", Erişim Tarihi: 15 Ağustos 2017, http://www.tuik.gov.tr/UstMenu.do?metod=temelist. 
Yayla, K. (2010). İnternet Pazarlamasında Yeni Eğilimler: Çevrimiçi Sosyal Ağların Üniversite Öğrencilerinin Satın Alma Davranışlarına Etkisi. Yüksek Lisans Tezi. Celal Bayar Üniversitesi Sosyal Bilimler Enstitüsü İşletme Anabilim Dalı, Manisa

Yazıc1, G., (2014). İnternetten Pazarlamada Yeni Bir Boyut: Sosyal Medyanın Tüketicilerin Marka Tercihlerine Etkisi Üzerine Bir Araştırma, Yüksek Lisans Tezi, Gazi Üniversitesi, Sosyal Bilimler Enstitüsü, Ankara.

Yazıcıoğlu, Y. ve Erdoğan, S. (2004). Spss uygulamalı bilimsel araştırma yöntemleri., Ankara: Detay Yayıncılık. 